\title{
Mediasi Pertanahan sebagai Model Alternatif Penyelesaian Sengketa Hak Ulayat Antara Masyarakat Adat Desa Eti dengan Pemerintah di Kabupaten Seram Bagian Barat Provinsi Maluku
}

\author{
La Ode Angga ${ }^{1 凶}$, Barzah Latupono $^{2}$ \\ 1,2 Faculty of Law, Pattimura University, Ambon. \\ Email: laodeangga@yahoo.com
}

\begin{abstract}
This study has long term goals, namely to find a model of dispute resolution of the Indigenous People of the Village of Eti with the Government in the West Seram (SBB). The method of approach used in this research is sociological juridical descriptive qualitative analysis. This study seeks to illustrate what happened in the Eti Indigenous community with the government around the conflict that occurred at the location of this study, namely the West Seram District (SBB). Data collection techniques used in this study are: Interviews, questionnaires and literature studies. Land mediation as an alternative model of dispute resolution between the people of Desa Eti and the SBB government in the following stages; first the team conducted a Dialogue, the Dialok was done well to the people of the Desa Eti with the government involved in a customary land dispute. This is done by the team to find out the desires of the parties in resolving the existing conflict. The second step is to negotiate the two parties involved in land conflicts. This is important in the context of the negotiation process between the two parties to the conflict in the land conflict both from the representatives of the two villages of Eti with the government with the aim of finding mutually beneficial solutions to each other so that both can be open and no one feels disadvantaged, negotiations in a place agreed by both parties. The third step is the team conducting Land Mediation. Mediation was carried out by both parties with the assistance of the team. The method used in this mediation is to resolve this conflict by mediating between the two groups involved in the conflict through the assistance of a neutral third party. The mediator who acts as the mediator has the task of explaining the process and helping both parties to resolve the conflict with the mediation stages prepared by the team. The fourth step is Peace Building (an attempt to restore conditions). We have carried out this effort with the aim of restoring the destructive state caused by violence in the conflict by building bridges of communication between the parties involved in the conflict between the people of Desa Eti and the government. And the fifth rarity is the follow-up supervision stage of the agreement that has been mutually agreed.
\end{abstract}

Keywords: Mediation of Land, Settlement of Disputes, Land Rights

Abstrak

Penelitian ini memiliki tujuan jangka panjang, yaitu menemukan model penyelesaian sengketa Masyarakat Asli Desa Eti dengan Pemerintah di Seram Barat (SBB). Metode pendekatan yang digunakan dalam penelitian ini adalah analisis kualitatif deskriptif yuridis sosiologis. Penelitian ini berupaya untuk menggambarkan apa yang terjadi pada masyarakat adat Eti dengan pemerintah di sekitar konflik yang terjadi di lokasi penelitian ini yaitu di Kabupaten Seram Barat (SBB). Teknik pengumpulan data yang digunakan dalam penelitian ini adalah: Wawancara, angket dan studi pustaka. Mediasi lahan sebagai model alternatif penyelesaian sengketa antara masyarakat Desa Eti dan pemerintahan SBB dengan tahapan sebagai berikut; pertama tim melakukan Dialog, Dialok dilakukan dengan baik kepada masyarakat Desa Eti dengan pemerintah yang terlibat sengketa tanah adat. Hal tersebut dilakukan oleh tim untuk mengetahui keinginan para pihak dalam menyelesaikan konflik yang ada. Langkah kedua adalah merundingkan kedua pihak yang terlibat dalam konflik lahan. Hal ini penting dalam rangka proses negosiasi antara kedua pihak yang berkonflik dalam konflik tanah baik dari perwakilan kedua desa Eti dengan pemerintah dengan tujuan untuk mencari solusi yang saling menguntungkan satu sama lain sehingga keduanya dapat menjadi satu sama lain. terbuka dan tidak ada yang merasa dirugikan, negosiasi di tempat yang disepakati oleh kedua belah pihak. Langkah ketiga adalah tim yang melakukan Mediasi Lahan. Mediasi dilakukan oleh kedua belah pihak dengan bantuan tim. Metode yang digunakan dalam mediasi ini adalah menyelesaikan konflik tersebut dengan melakukan mediasi antara dua kelompok yang terlibat konflik melalui bantuan pihak ketiga yang netral. Mediator yang bertindak sebagai mediator bertugas menjelaskan proses dan membantu kedua belah pihak untuk menyelesaikan konflik dengan tahapan mediasi yang disiapkan oleh tim. Langkah keempat adalah Peace Building (upaya untuk memulihkan kondisi). Upaya ini kami lakukan dengan tujuan untuk memulihkan keadaan rusak akibat kekerasan dalam konflik dengan membangun jembatan komunikasi antara pihak-pihak yang terlibat konflik antara masyarakat Desa Eti dan pemerintah. Dan kelangkaan kelima adalah tahap pengawasan tindak lanjut dari kesepakatan yang telah disepakati bersama.

Kata Kunci: Mediasi Tanah, Penyelesaian Sengketa, Hak Atas Tanah 


\section{Pendahuluan}

Indonesia merupakan Negara kepulauan yang terdiri dari 13.579 buah pulau besar dan kecil yang dihubungkan dengan laut. Sekitar $70 \%$ wilayah Indonesia terdiri dari laut. ${ }^{1}$ Dari $70 \%$ tersebut di dalamnya masuk Provinsi Maluku. Secara Astronomi Provinsi Maluku terletak antara 2 30'-8 30' Lintang Selatan dan 124-135 30' Bujur Timur, dengan luas wilayah 712.479,65 $\mathrm{Km} 2(7,6 \%)$ ialah luas daratan dan $658.294,69 \mathrm{Km} 2(92,4 \%)$ adalah luas lautan. ${ }^{2}$

Sebagai provonsi kepulauan, Maluku memiliki 32 pulau besar dan kecil. Pulau-pulau dimaluku antara lain Pulau Seram, Pulau Buru, Pulau Yamdena dan Pulau Wetar. Dengan kondisi wilayah yang dominan perairan, Provinsi Maluku sangat terbuka untuk berintegrasi dengan provinsi-provinsi dan negara sekitar. ${ }^{3}$ Di didalam masyarakat Adat di Provinsi Maluku sering terjadi konflik diantaranya adalah konflik hak ulayat (hak petuanan) antara masyarakat dengan investor atau masyarakat dengan pemerintah dan masyarakat dengan masayarkat itu sendiri. Ambil contoh konflik yang terjadi di Kabupaten Seram Bagian Barat (SBB). Di SBB konflik terjadi antara masyarakat Desa Eti dengan pemerintah setempat dalam hal pemanfaatan hak ulayat (petuanan).

Banyak konflik tanah adat di pengadilan yang diselesaikan dengan hasil yang kurang memuaskan, sehingga berkembang pandangan di masyarakat bahwa badan peradilan tidak optimal dalam menyelesaikan sengketa pertanahan. Akibatnya, rasa keadilan dan kepastian hukum yang diharapkan masyarakat tidak terpenuhi, bahkan yang ada hanyalah persoalan baru yang dampaknya justru memperburuk kondisi yang ada. Pola penyelesaian konflik pertanahan di luar pengadilan dapat dilakukan dengan cara negosiasi, musyawarah mufakat dan mediasi. Negosiasi dilakukan dengan jalan dimana para pihak yang berkonflik duduk bersama untuk mencari jalan terbaik dalam penyelesaian konflik dengan prinsip bahwa penyelesaian itu tidak ada pihak yang dirugikan (win-win solution). Musyawarah mufakat adalah lengkah lebih lanjut dari negosiasi. Jika dalam negosiasi tidak terdapat kesepakatan yang saling menguntungkan, maka langkah lebih lanjut adalah melakukan musyawarah mufakat dengan melibatkan pihak lain selaku penengah. Hasil musyawarah tersebut selanjutnya dibuatkan surat kesepakatan bersama yang ditanda tangani oleh para pihak dan para saksi.

Mediasi pertanahan merupakan pengendalian konflik pertanahan yang dilakukan dengan cara membuat konsensus diantara dua pihak yang berkonflik untuk mencari pihak ketiga yang berkedudukan netral sebagai mediator dalam penyelesaian konflik. Penyelesaian secara mediasi baik yang bersifat tradisional ataupun melalui berbagai Lembaga Alternative Dispute Resolution (ADR) mempunyai kelebihan bila dibandingkan dengan berperkara di muka pengadilan yang tidak menarik dilihat dari segi waktu, biaya dan pikiran/tenaga. Disamping itu kurangnya kepercayaan atas kemandirian lembaga peradilan dan kendala administrasi yang meliputinya membuat pengadilan merupakan pilihan terakhir untuk penyelesaian sengketa.

Dengan latar belakang di atas maka tim peneliti bertujuan merumuskan model Penyelesaian Sengketa Hak Ulayat Antara Masyarakat Adat Desa Eti Dengan Pemerintah Di Kabupaten Seram Bagian Baratdi provinsi Maluku sebagai jawaban dari kompleksnya permasalahan yang dihadapi saat ini dengan tujuan akhirnya adalah untuk meminimalisir konflik yang muncul pada masyarakat adat di Provinsi Maluku, serta sebagai input (masukan) bagi Pemerintah Provinsi Maluku dalam merumuskan kebijakan bagi masyarakat adat.

Wartini Soegeng, Pengukuran kapal Indonesia (Aspek Hukum) PT Refika Aditama, Bandung, 2000, hlm. 3.

Model Pengelolaan Sumber Daya Pesisir, Dikutip dari laman: http://www.boyyendratamin.com/2013/09/modelpengelolaan-sumber-daya-pesisir.html, diakses tanggal 21 Maret 20017.

3 Ibid. 


\section{Rumusan Masalah}

Berdasarkan uraian pendahuluan diatas, permasalahan yang dikaji dalam tulisan ini yakni: Pertama, mengapa penyelesaian sangketa antara masyarakat lokal dan pemerintah tidak dapat diselesaikan melalui pengadilan; Kedua, bagaimana model penyelesaian sangketa yang digunakan untuk menyelesaikan sangketa antara pemerintah dengan masyarakat lokal.

\section{Metodologi Penelitian}

Penelitian ini dilakukan dengan menggunakan pendekatan yuridis emperis yang bersifat kajian deskriptif analisis kualitatif. ${ }^{4}$ Penelitian berusaha untuk menggambarkan apa yang terjadi dalam masyarakat Desa Eti di Provinsi Maluku. Lokasi penelitian ini ada di Kabupaten Seram Bagian Barat (SBB). Di SBB tim peneliti mengambil lokasi Desa Eti. Kemudian diambil 10 orang yang tinggal disekitar pesisir yang terjadinya konflik hak ulayat sebagai responden. Sumber data yang digunakan dalam penelitian ini, adalah data sekunder (secondary data) dan data primer (primary data). Penelitian bersifat deskriptif, ingin memberikan gambaran Apa yang menyebabkan terjadinya konflik Hak ulayat adat di Desa Eti? Kemudian bagaimana penyelesaian konflik tersebut?. Seluruh data telah dikumpulkan baik data primer maupun data sekunder, dipelajari dan dianalisis secara mendalam sehingga diperoleh suatu kesimpulan yang utuh dan mendalam.Teknik yang digunakan untuk menganalisis data, baik data primer maupun data sekunder yang telah terkumpul dari studi dokumen serta bahan pustaka diidentifikasi lalu dikelompokkan, ditelaah serta diuraikan menurut hirarkhinya.

\section{Hasil Dan Pembahasan}

\section{Pengertian Konflik Pertanahan}

Konflik merupakan hal yang bersifat niscaya, timbul dilatarbelakangi oleh gesekan antar perbedaan baik individu maupun golongan. Konflik sebenarnya adalah sebuah hal yang tidak diinginkan oleh pihak manapun, siapa pun melakukan berbagai cara untuk menghindarkan dirinya sejauh mungkin dari konflik, namun karena konflik bersifat niscaya maka tidak ada satu masyarakat pun yang tidak pernah mengalami konflik, baik individu, antar anggotanya atau dengan golongan masyarakat lainnya, konflik hanya akan hilang bersamaan dengan hilangnya masyarakat itu sendiri. Konflik adalah aspek intrinsik dan tidak mungkin dihindarkan dalam perubahan sosial. Konflik adalah sebuah ekspresi heterogenitas kepentingan, nilai, dan keyakinan yang muncul sebagai formasi baru yang ditimbulkan oleh perubahan sosial yang muncul bertentangan dengan hambatan yang diwariskan. Perbedaanperbedaan tersebut diantaranya adalah menyangkut perbedaan kepentingan, kebutuhan, ciri fisik, pemahaman, posisi, adat istiadat, keyakinan, dan lain sebagainya.

Solusi penyelesaian yang kami tawarkan terhadap konflik yang terjadi antara masyarakat Desa Eti dengan pemerintah yaitu melakukan perdamaian dengan Model Mediasi Sengketa Pertanahan sebagai salah satu alternatif penyelesaian konflik pertanahan yang terjadi. Ditinjau dari segi efektifnya penyelesaian lewat mediasi sengketa pertanahanan sudah terbukti dibeberapa konflik pertanahan yang terjadi di beberapa tempat di Indonesia. Mediasi sengketa pertanahan sebagai model penyelesaian konflik telah dikenal sebagai kearifan lokal dalam masyarakat hukum Adat yang ada di Indonesia, antara lain pada sengketa pertanahan yang ada di pulau jawa, Kalimatan, Sumatra termaksud Aceh. ${ }^{5}$ Dalam penyelesaian mengenai masalah konflik pertanahan kedua masyarakat desa tersebut dengan pihak pengusaha industri pengolahan udang dilakukan dengan model mediasi sengketa pertanahan. Mediasi sengketa pertanahan tersebut dilakukan dengan melibatkan pihak ketiga dalam hal ini mediator pihak ketiga yang independen, mandiri dan bisa dihormati oleh kedua pihak yang berkonflik.

\footnotetext{
Maria SW, Sumardjono, Pendoman Pembuatan Usulan Penelitian Sebuah Panduan Dasar, Penerbit Gramedia Pustaka Utama. Jakarta, hlm. 10.

5 Saufi Ahmad, Mediasi Penal Sebagai Alternatif Penyelesaian Perkara Pidana Beraspek Perikatan, Ringkasan Disertasi, Program Doktor Ilmu Hukum Fakultas Hukum Universitas Brawijaya Malang, 2013, hlm. 18.
} 
Mediator dalam menyelesiakan konflik tersebut dilakukan dengan cara musyawarah untuk menemukan titik temu kedua pihak yang berkonflik. Dalam wawancara kami sebagai tim peneliti pada tanggal 26-27 Februari 2017 yang lalu pada umumnya masyarakat Desa Eti telah melakukan tuntutan lewat pengadilan namun semua hasilnya nihil karena kebanyakan tidak memiliki bukti formal, seperti sertifikat, oleh karena itu masyarakat Desa Eti yang berkonflik dengan pemerintah sepakat diselesaiakan dengan bentuk alternatif di luar pengadilan atau non litigasi.

Jalan yang banyak ditempuh yakni non-litigasi (di luar pengadilan) bahkan melalui jalur tekanan massa, lobi-lobi politik di DPRD. Lembaga politik menjadi ajang penyelesaian konflik hukum, namun imbasnya hukum semakin terkebelakang dan jalur alternatif politik dipakai sebagai ganti cara menghaluskan kekerasan. Banyak konflik tanah adat di pengadilan yang diselesaikan dengan hasil yang kurang memuaskan, sehingga berkembang pandangan di masyarakat bahwa badan peradilan tidak optimal dalam menyelesaikan sengketa pertanahan. Akibatnya, rasa keadilan dan kepastian hukum yang diharapkan masyarakat tidak terpenuhi, bahkan yang ada hanyalah persoalan baru yang dampaknya justru memperburuk kondisi yang ada. Pola penyelesaian konflik pertanahan di luar pengadilan dapat dilakukan dengan cara negosiasi, musyawarah mufakat dan mediasi. Negosiasi dilakukan dengan jalan dimana para pihak yang berkonflik duduk bersama untuk mencari jalan terbaik dalam penyelesaian konflik dengan prinsip bahwa penyelesaian itu tidak ada pihak yang dirugikan (win-win solution). Musyawarah mufakat adalah langkah lebih lanjut dari negosiasi. Jika dalam negosiasi tidak terdapat kesepakatan yang saling menguntungkan, maka langkah lebih lanjut adalah melakukan musyawarah mufakat dengan melibatkan pihak lain selaku penengah. Hasil musyawarah tersebut selanjutnya dibuatkan surat kesepakatan bersama yang ditanda tangani oleh para pihak dan para saksi.

Mediasi merupakan pengendalian konflik pertanahan yang dilakukan dengan cara membuat konsensus diantara dua pihak yang berkonflik untuk mencari pihak ketiga yang berkedudukan netral sebagai mediator dalam penyelesaian konflik. Penyelesaian secara mediasi baik yang bersifat tradisional ataupun melalui berbagai Lembaga Alternative Dispute Resolution (ADR) mempunyai kelebihan bila dibandingkan dengan berperkara di muka pengadilan yang tidak menarik dilihat dari segi waktu, biaya dan pikiran/tenaga. Disamping itu kurangnya kepercayaan atas kemandirian lembaga peradilan dan kendala administrasi yang meliputinya membuat pengadilan merupakan pilihan terakhir untuk penyelesaian sengketa.

\section{Model Penyelesaian Mediasi Melalui Sengketa Pertanahan}

Tahapan-tahapan atau langkah-langkah dalam melaksanakan solusi yang ditawarkan untuk mengatasi permasalahan yang memuat hal-hal berikut ini:

\section{a. Dialog}

Kami tim pertama kali melakukan langka dialog, dialok ini dilakukan baik kepada masyarkat kedua desa yaitu Desa Arara dan Desa Salemnag disatu sisi sebagai yang menderita kerugian akibat dari sengketa pertanahan tersebut dan, dialok juga dialakukan kepada pihak infestor dalam hal ini pemilik usaha industri pengolahan udang didua desa tersebut di atas. Hal ini kami lakukan untuk mengetahui keinginan para pihak dalam penyelesaian konflik yang ada tersebut. Dialok ini kami lakukan tentu saja meruakan langka awal untuk nantinya menentukan solusi atau jalan keluar yang harus ditawarkan dalam masalah sengketa tanah yang ada.

Setelah melakukan dialok dengan masing-masing, selanjutnya tim akam melakukan dialog dengan kedua bela pihak dalam satu meja artinya mempertemukan mereka yang bersengketa dalam satu tempat. Hal ini atau tahapan ini penting dilakukan oleh tim untuk menggali informasi yang dinginkan kedua bela pihak sehingga tim bisa mengambil solusi yang tepat dalam masalah ini. 
Untuk melakukan dialog, tersebut kami tim menyarankan atau bemberikan informasi terlebih dahulu kepeda kedua pihak yang berkonflik supaya pelaksanaan dialok lancar kedua belah pihak yang terlibat dalam konflik pertanahan yang ada harus memperhatikan beberapa hal yaitu:

1) Harus saling terbuka antara kedua bela pihak;

2) Adanya pijakan yang sama atau titik temu sehingga bisa mendapatkan solusi;

3) Tujuan yang sama pula yaitu untuk saling memahami satu sama lain;

4) Harus mengangap mitra yang sejajar diantara keduanya tidak boleh ada yang merasa di atas dan sebaliknya tidak boleh yang merasa ada di bawah.

\section{b. Negosiasi}

Langka kedua yang tim lakukan yaitu melakukan negosiasi kepada kedua pela pihak yang terlibat konflik pertanahan. Hal ini penting tim lakukan dalam rangka proses peundingan dua pihak yang bertikai dengan konflik pertanahan baik wakil kedua desa yaitu Desa Arara dan Desa Salemang, dengan tujuan untuk mencari solusi penyelesaian bersama yang saling menguntungkan, satu sama lain sehingga keduanya bisa terbuka dan tidak ada yang saling merasa dirugikan. Tim melakukan negosiasi ditempat yang telah disepakati oleh kedua bela pihak.

Dalam beberapa literatur dijelaskan diantaranya Syahrizal Abbas berpendapat bahwa negosiasi adalah salah satu strategi penyelesaian sengketa atau konflik dimana para pihak setuju untuk menyelesaikan persoalan mereka melalui proses musyawarah dan perundingan. Dengan kata lain, negosiasi adalah suatu proses struktur dimana para pihak yang bersengketa berbicara sesama mereka mengenai persoalan yang dipeselisihkan dalam rangka mencapai persetujuan atau kesepakatan bersama. ${ }^{6}$

Sebelum negosiasi tim lakukan terlebih dahulu tim memberikan informasi atau menganjurkan kepada kedua bela pihak untuk melakukan negosiasi dengan beberapa syarat. Hal ini tim lakukan agar kedua bela pihak patu dan mengindakan sayarat-syarat untuk melakukan negosiasi antara lain:

1) Bersedia membagi kepentingan bersama

2) Sepakat dalam prosedur negosiasi yang ditempuh

3) Bersifat sukarela

4) Saling dipercaya

5) Mencari berbagai alternatif dalam mencari solusi (jika deadlock dapat dilanjutkan pada kesempatan lain).

Tujuan tim melakukan negosiasi ini adalah untuk mendapatkan penyelesaian masalah bersama antara kedua bela pihak yang berkonflik dengan beberapa perbedaan yang ada sehingga mendapatkan penyelesaian yang saling menguntungkan (win-win solution) bukan saling merugika (lose-lose solution) maupun menang kalah (win-lose). Oleh karena itu, dalam proses negosiasi kedua belah pihak yang berkonflik diharapkan dapat melakukan kompromisasi dengan baik dalam rangka mencapai tujuan yang saling menguntungkan.

\section{c. Mediasi Pertanahan}

Tahapan ketiga tim melakukan langka mediasi yang berarti menengahi. Mediasi merupakan sebuah proses dimana kedua bela pihak yang berkonflik yaitu Desa Arara dan Desa Salemang dengan perusahaan industri pengolahan udang. Kedua bela pihak tersebut dengan bantuan dari tim melakukan mediasi. Metode yang tim lakukan dalam penyelesaian konflik ini dengan cara menengahi kedua kelompok di atas yang saling terlibat konflik melalui bantuan

\footnotetext{
6 Syahrizal Abbas, MEDIASI dalam Hukum Syari'at, Hukum Adat, dan Hukum Nasional, hlm. 9-10.
} 
pihak ketiga yang netral. Pelaku mediasi yang bertugas sebagai penengah disebut dengan mediator yang bertugas menjelaskan proses dan membantu kedua belah pihak untuk menyelesaikan konflik dengan tahapan-tahapan mediasi yang telah disiapkan.

Sebelum tim melakukan mediasi pertanahan tersebut pertama-tama tim menyampaikan beberapa hal yang harus diperhatikan, supaya bisa efektif dan berjalan lancea yaitu:

1) Mediasi dilakukan dengan itikad baik;

2) Mediasi dilakukan dengan penuh rasa kekeluargaan tanpa ada beban;

3) Menganggap kedua bela pihak yang berkonfik dalam sebuah keluarga besar;

4) Setelah melakukan mediasi harus ada tindak lanjut (Follow up), merupakan pelaksanaan hasil-hasil kesepakatan oleh kedua belah pihak yang berkonflik dan dituangkan secara bersama-sama dalam perjanjian tertulis.

d. Peace Building (Upaya mencoba mengembalikan kedaan)

Upaya ini kami lakukukan denga tujuan mengembalikan keadaan destruktif akibat kekerasan yang terjadi dalam konflik dengan cara membangun jembatan komunikasi antar pihak yang terlibat dalam konflik antara Desa Arara dan Desa Salemang dengan industri pengolahan udang di kedua lokasi tersebut. Menurut Johan Galtung Peace Building yaitu strategi atau upaya yang mencoba mengembalikan keadaan destruktif akibat kekerasan yang terjadi dalam konflik dengan cara membangun jembatan komunikasi antar pihak yang terlibat dalam konflik. ${ }^{7}$

\section{Penutup}

\section{Kesimpulan}

Mediasi pertanahan sebagai model alternatf penyelesaian sengkata antara masyarakat Desa Eti dan pemerintah SBB melalui tahap sebagai berikut:

a. Tim melakukan Dialog, dialok di lakukan baik kepada masyarkat Desa Eti dengan pemerintah yang terlibata sengketa hak ulayat. Hal ini tim lakukan untuk mengetahui keinginan para pihak dalam penyelesaian konflik yang ada tersebut.

b. Melakukan Negosiasi kepada kedua pela pihak yang terlibat konflik pertanahan. Hal ini penting dilakukan dalam rangka proses perundingan dua pihak yang bertikai dalam konflik pertanahan baik dari wakil kedua Desa Eti denga pemerintah dengan tujuan untuk mencari solusi penyelesaian bersama yang saling menguntungkan, satu sama lain sehingga keduanya bisa terbuka dan tidak ada yang saling merasa dirugikan, negosiasi ditempat yang telah disepakati oleh kedua bela pihak.

c. Tim melakukan Mediasi Pertanahan. Mediasi dilakukan Kedua bela pihak tersebut dengan bantuan dari tim. Metode yang dilakukan dalam mediasi ini untuk menyelesikan konflik ini dengan cara menengahi kedua kelompok di atas yang saling terlibat konflik melalui bantuan pihak ketiga yang netral.

d. Peace Building (upaya mencoba mengembalikan kedaan). Upaya ini kami lakukukan denga tujuan mengembalikan keadaan destruktif akibat kekerasan yang terjadi dalam konflik dengan cara membangun jembatan komunikasi antar pihak yang terlibat dalam konflik antara masyarakat Desa Eti dengan pemerintah tersebut. Dan langka kelima yaitu tahap pengawasan tindak lanjut dari kesepakan yang sudah disepakati bersama.

\section{Saran}

M. Mukhsin Jamil, Mengelola konflik membangun Damai, hlm. 72 
Kosmik Hukum Vol. 20 No. 2 (2020): 114-120

E-ISSN: 2655-9242 | P-ISSN: 1411-9781

DOI: 10.30595/kosmikhukum.v20i2.7541

Sebagai peneliti kami tim menyerangkan sebaiknya dalam penyelesaian sengketa hak ulayat sebaiknya pilihan yang pertama menggunakan instrumen penyelesaian sengketa melalui jalur diluar pengadilan (Non Litigasi), bila jalur diluar pengadilan menemukan jalan buntu makan instrumen yang berikutnya adalah penyelesaian sengketa lewat pengadilan (Litigasi)

\section{Daftar Pustaka}

Anonym, Aspek Hukum Dakam Ekonomi, https://aditz19.wordpress.com/2011/03/12/ pengertian-mediasi/ diakses tanggal 14 Nopemeber 2017.

Anonym, Aspek Hukum Dakam Ekonomi, https://aditz19.wordpress.com/2011/03/12/ pengertian-mediasi/ diakses tanggal 14 Nopemebr 2017.

http://www.boyyendratamin.com/2013/09/model-pengelolaan-sumber-daya-pesisir.html, diakses tanggal 21 Maret 20017.

http://www.boyyendratamin.com/2013/09/model-pengelolaan-sumber-daya-pesisir.html, diakses tanggal 21 Maret 20017.

M. Mukhsin Jamil, Mengelola konflik membangun Damai.

Ronny Hanitijo Soemitro, Metodologi Penelitian Hukum dan Jurimetri, Cetakan Kelima, Ghalia Indonesia, Jakarta, 1994.

Saufi Ahmad, Mediasi Penal Sebagai Alternatif Penyelesaian Perkara Pidana Beraspek Perikatan, Ringkasan Disertasi, Program Doktor Ilmu Hukum Fakultas Hukum Universitas Brawijaya Malang.

Soegeng,Wartini, Pengukuran kapal Indonesia (Aspek Hukum) PT Refika Aditama, Bandung, 2000.

Soemitro Ronny Hanitijo, Metodologi Penelitian Hukum dan Jurimetri, Cetakan Kelima, Ghalia Indonesia, Jakarta, 1994.

Sudharto, 2002, Resolusi Konflik Lingkungan, Lihat juga di http://selamatkanlingkungan99.blogspot.co.id/2014/07/konflik-lingkunganhidup.html, diakses tanggal 31 Maret 2017.

Sudharto, 2002, Resolusi Konflik Lingkungan,Lihat juga di http://selamatkanlingkungan99.blogspot.co.id/ 2014/07/konflik-lingkunganhidup.html, diakses tanggal 31 Maret 2017.

Sumardjono, SW. Maria, Sumardjono, Pendoman Pembuatan Usulan Penelitian Sebuah Panduan Dasar, Penerbit Gramedia Pustaka Utama. Jakarta, 2003.

Supryono, Harry, Manajemen Konflik dan penyelesaian masalah lingkungan, Kursus AMDAL Tipe A Kerja sama PSLH UGM dengan kemetrian lingkungan, 2003.

Syahrizal Abbas, MEDIASI dalam Hukum Syari'at, Hukum Adat, dan Hukum Nasional.

Wartini Soegeng, Pengukuran kapal Indonesia (Aspek Hukum) PT Refika Aditama, Bandung, 2000. 